УДК 638.141

(C) 2015

Шамро М. О., кандидат сільськогосподарських наук, Шамро Л. П., старший науковий співробітник,

Соловйова Т. М., технік

Національний науковий центр «Інститут бджільництва імені П. І. Прокоповича»

\title{
ВПЛИВ СПОСОБІВ СТВОРЕННЯ ЗАПАСІВ КОРМУ НА ВИРОЩУВАННЯ БДЖІЛ У ПЕРІОД ОСІННЬОЇ РОТАЦІї ЇХ ГЕНЕРАЦІЙ
}

\section{Рецензент - кандидат сільськогосподарських наук С. І. Бугера}

На основі експериментальних досліджень в умовах лісостепової зони Украӥни зроблено порівняльний аналіз підготовки бджслиних сімей до зимівлі на природному кормі і з використанням иукрового корму. Незважаючи на те, щзо під час поповнення запасів корму на зиму иляхом згодовування иукрового сиропу, період від початку зменшення до припинення виховання розплоду збільшується на 17,8\%, а кількість вихованого розплоду за иеей період - на 9,8\%, кількість корму на одну вуличку бджіл і сила сімей на початку зими зменшується відповідно на 4,7\% і 16,4\%.

Ключові слова: бджолині сім $і$, кормові запаси, осіння ротаџія генерацій бджіл, вирощування бджіл.

Постановка проблеми. Одним із факторів, що впливає на якість зимувалих бджолиних сімей, $\epsilon$ забезпечення їх кормом під час підготовки до зимового періоду. Утримання бджіл за такого стану потребує вивчення умов їх життєдіяльності та наукового обгрунтування комплексу прийомів, що сприяють зміні генерацій бджіл у передзимовий період, забезпеченню запасами корму, зокрема осінньої підгодівлі їх цукровим сиропом.

Аналіз останніх досліджень і публікацій, у яких започатковано розв'язання проблеми. На сучасному етапі розвитку сільського господарства України все більше приділяється уваги бджільництву як галузі, що забезпечує запилення ентомофільних сільськогосподарських культур i виробляє різноманітну продукцію. Кількість зібраного бджолами меду значною мірою залежить від стану сімей.

Відомо, що в період підготовки до зими кількість бджіл у бджолиних сім'ях значно зменшується, оскільки в кінці літа відмирають особини червневої і липневої генерацій $[2,5,3]$. Зменшення i завершення медозбору призводить до поступового скорочення вирощування розплоду. Припинення відкладання маткою яєць припадає на другу половину вересня, а в південних районах України - на початок жовтня [7].

Наведені факти пристосувальних біологічних особливостей у структурі бджолиних сімей є загальними для різних умов їх утримання. Також необхідно визнати вплив на структуру бджолиних сімей технологічних прийомів догляду.

Мета дослідження - науково обгрунтувати систему прийомів з підготовки бджолиних сімей до зимівлі.

Завдання дослідження - дослідити вплив способів створення запасів корму на виховання бджіл у період осінньої ротації генерацій і якість зимівлі сімей.

Методика проведення досліджень. Дослідження проводили в природно-кліматичних умовах лісостепової зони України - у Полтавській та Сумській областях - на базі пасік дослідного господарства Національного наукового центру «нститут бджільництва ім. П. І. Прокоповича».

На початку досліджень визначення впливу способу створення запасів корму на виховання бджіл у період осінньої ротації генерацій сімей за результатами головної весняної ревізії, яку проводили в середині березня, відбирали 20 бджолиних сімей. Відібрані бджолині сімі розподіляли на дві групи по 10 сімей-аналогів у кожній. Перша група - контрольна, сім’і якої готували зимувати на квітковому меді, що був заготовлений ними в першій половині літа. Друга група бджолиних сімей була дослідною, їх підгодовували цукровим сиропом 31 до 15 вересня. Загалом на зиму сім’і цієї групи заготовляли корм, що містив 50 \% квіткового меду та $50 \%$ меду, виготовленого із цукрового сиропу.

Силу бджолиних сімей обліковували за кількістю вуличок. Згідно з загальноприйнятою методикою вуличка між рамками розміром 435х300 см вміщує в середньому 250 г бджіл $[4,1]$.

Кількість розплоду в піддослідних сім'ях вимірювали за допомогою рамки-сітки з квадратами $5 \times 5$ см. В одному квадраті на площі $25 \mathrm{~cm}^{2}$ вміщується 100 бджолиних комірок. Діленням усієї суми печатного розплоду на 12 встановлювали середню його кількість, яку бджолині сім'“і вигодовували за один день [4]. Кількість одержува- 


\section{СІЛЬСЬКЕ ГОСПОДАРСТВО. ТВАРИННИЦТВО}

ного товарного меду визначали зважуванням відібраних з гнізда медових стільників до і після відкачування 3 них меду, валову кількість меду за сумою відібраного товарного і залишеного в сім’ї як кормовий запас, воскопродуктивність піддослідних сімей - за кількістю відбудованих протягом сезону стільників на вощині.

Біометричну обробку отриманих у дослідах даних виконували методом варіаційної статистики [6].

Результати досліджень. У природних умовах кормові запаси для своїх потреб на зимовий період бджолині сім’ї заготовляють упродовж весни і літа. На практиці бувають випадки, коли в їх гніздах залишається недостатня кількість корму. Інколи 3 метою збільшення кількості товарного меду чи заміни падевого, пасічник відбирає у бджіл частину кормових запасів.

У такому разі виникає необхідність підгодовування сімей на зиму цукровим сиропом.

Підгодівля бджолиних сімей узимку цукровим сиропом частково змінює природні умови їх життєдіяльності. Тому нами було проведено дослід 3 метою вивчення впливу заготівлі бджолиними сім'ями зимових кормових запасів (квіткового меду в літній період та корму 3 цукру в кінці сезону) на їх розвиток. На кінець липня розвиток бджолиних сімей досягав свого природного максимуму.

У дослідній групі сімей виховання розплоду бджіл на початку третьої декади липня становило в середньому $1750 \pm 13,44$, а у контрольній $-1735 \pm 6,74$ комірок за добу ( $>0,1)$, а в кінці третьої декади липня - зменшувалось і в першій декаді серпня дорівнювало відповідно $1295 \pm 2,22$ і 1301 $\pm 5,19$ особин на добу ( $>0,1)$. У кінці серпня добове виховання бджіл зменшилося до $804 \pm 11,43$ особин у дослідній i $796 \pm 2,06$ - контрольній групі ( $>00,1)$. Таким чином, починаючи 3 середини третьої декади липня, бджоли поступово зменшували вирощування розплоду незалежно від наявності продуктивного медозбору i, як наслідок, зменшувалась їх сила. Як показують результати обліків, за період від початку формування контрольної та дослідної груп бджолиних сімей і до кінця серпня суттєвих від- мінностей в їх розвитку і продуктивності не спостерігали.

У першій половині літа від дослідних бджолиних сімей відбирали по 5 стільників масою 2,2-2,7 кг кожний як корм для зимівлі. В середньому на сім'ю було відібрано 12,5 $\pm 0,08$ кг стільникового меду.

Товарний мед від бджолиних сімей відбирали двічі: перший раз після медозбору з гречки в другій половині липня, другий - 3 гречки і соняшнику в другій декаді серпня. Від бджолиних сімей дослідної групи отримано 29,4 $\pm 0,33$ кг товарного меду, а від контрольної - 16,6 $\pm 0,26$ кг. У зв'язку з тим, що у бджолиних сім'ях дослідної групи половину необхідного для зимівлі меду замінили кормом 3 цукрового сиропу, від них отримали товарного меду на $77,1 \%$ більше (табл. 1$)$.

Згідно з отриманими результатами продуктивності бджолиних сімей у випадку різних способів заготівлі кормових запасів на зиму, за кількістю відбудованих стільників на штучній вощині та валовій кількості меду не встановлено вірогідної різниці між дослідною і контрольною групами. 3 другої декади вересня між контрольною і дослідною групами бджолиних сімей відмічали різницю за кількістю вирощеного розплоду за добу.

На початку першої половини вересня припинявся підтримуючий медозбір. Через 7-10 діб після цього матки у бджолиних сім'ях контрольної групи переставали відкладати яйця, а бджоли закінчували вирощувати розплід на початку першої половини жовтня.

Бджолиним сім'ям дослідної групи згодовували цукровий сироп для поповнення кормових запасів на зимовий період у першій половині вересня. Тому в них бджолині матки продовжували відкладати яйця, а бджоли - відповідно вирощувати розплід.

У сім’ях дослідної групи матки припиняли відкладати яйця через 7-10 діб після закінчення підгодівлі їх на зиму (середина третьої декади вересня), а бджоли закінчували виховання розплоду в другій половині жовтня.

\section{1. Продуктивність бджслиних сімей за різних способів заготівлі кормових запасів на зиму, п=20}

\begin{tabular}{|c|c|c|c|c|c|c|}
\hline \multirow{3}{*}{ Показник } & \multicolumn{5}{|c|}{ Група сімей } & \multirow{3}{*}{$\begin{array}{c}\% \text { до } \\
\text { контролю }\end{array}$} \\
\hline & \multicolumn{2}{|c|}{ контрольна } & \multicolumn{3}{|c|}{ дослідна } & \\
\hline & $\mathrm{M} \pm \mathrm{m}$ & $\mathrm{Cv}, \%$ & $\mathrm{M} \pm \mathrm{m}$ & $\mathrm{Cv}, \%$ & td & \\
\hline Товарний мед, кг & $16,6 \pm 0,26$ & 4,99 & $29,4 \pm 0,33$ & 3,55 & - & 177,1 \\
\hline Валовий мед, кг & $39,6 \pm 0,17$ & 1,36 & $40,2 \pm 0,36$ & 2,83 & 1,53 & 101,5 \\
\hline $\begin{array}{l}\text { Відбудовано стільників } \\
\text { на штучній вощині, шт. }\end{array}$ & $5,1 \pm 0,03$ & 1,87 & $5,2 \pm 0,04$ & 0,24 & 1,80 & 101,9 \\
\hline
\end{tabular}


СІЛЬСЬКЕ ГОСПОДАРСТВО. ТВАРИННИЦТВО

2. Вилив способу створення запасів корму на підгтовку сімей до зими, $n=20$

\begin{tabular}{|c|c|c|c|c|c|c|}
\hline \multirow{3}{*}{ Показник } & \multicolumn{5}{|c|}{ Група сімей } & \multirow{3}{*}{$\begin{array}{c}\% \text { до } \\
\text { контролю }\end{array}$} \\
\hline & \multicolumn{2}{|c|}{ контрольна } & \multicolumn{3}{|c|}{ дослідна } & \\
\hline & $\mathrm{M} \pm \mathrm{m}$ & $\mathrm{Cv}, \%$ & $\mathrm{M} \pm \mathrm{m}$ & $\mathrm{Cv}, \%$ & $\mathrm{td}$ & \\
\hline $\begin{array}{c}\text { Кількість корму на одну } \\
\text { вуличку бджіл, кг }\end{array}$ & $\begin{array}{l}2,7 \pm \\
0,02\end{array}$ & 2,36 & $\begin{array}{l}2,6 \pm \\
0,01\end{array}$ & 0,01 & 0,01 & 96,3 \\
\hline $\begin{array}{c}\text { Сила під час останнього } \\
\text { обльоту, вуличок }\end{array}$ & $\begin{array}{l}6,1 \pm \\
0,11\end{array}$ & 5,64 & $\begin{array}{l}5,1 \pm \\
0,14\end{array}$ & 0,87 & $6,00 * * *$ & 83,6 \\
\hline $\begin{array}{c}\text { Період від початку зменшення } \\
\text { до припинення вирощування } \\
\text { розплоду, діб }\end{array}$ & $71,3 \pm 0,88$ & 3,90 & $84,0 \pm 1,15$ & 4,35 & $8,80 * * *$ & 117,8 \\
\hline $\begin{array}{c}\text { Кількість розплоду в період } \\
\text { від початку зменшення до } \\
\text { припинення його вирощування, } \\
\text { тис. комірок }\end{array}$ & $62,1 \pm 0,21$ & 1,07 & $68,2 \pm 0,42$ & 1,95 & $12,95 * * *$ & 109,8 \\
\hline
\end{tabular}

Примітка: *** $\mathrm{p}<0,001$

3 розрахунку на одну вуличку бджіл кількість корму, що залишали на зиму, в дослідній групі становила 2,6 $\pm 0,01$ кг, у контрольній $-2,7 \pm 0,02$, різниця невірогідна. За різних способів забезпечення бджолиних сімей кормами на зимівлю період від початку зменшення до припинення виховання розплоду в них був різним. У дослідній групі бджолиних сімей він дорівнював у середньому $84,0 \pm 0,74$, а в контрольній $-71,0 \pm 0,43$ доби $(\mathrm{p}<0,001)$. Хоч у бджолиних сім'ях дослідної групи зменшення темпів розвитку відбувалося повільніше і вони виростили вірогідно більшу ( $<<0,001)$ кількість розплоду (в середньому на 6,1 тис. комірок), їх сила на час останнього обльоту була меншою в середньому на одну вуличку бджіл 3 вірогідною $(\mathrm{p}<0,001)$ різницею в середньому на одну вуличку бджіл (табл. 2).

Таким чином, незважаючи на те, що у випадку поповнення запасів корму на зимовий період шляхом згодовування цукрового сиропу період від початку зменшення до припинення виховання

\section{БІБЛІОГРАФІЯ}

1. Колесниченко В. В., Черевко Ю. А. Точность определения силы пчелиных семей / В. В. Колесниченко, Ю. А. Черевко // Пчеловодство. - 2005. №5. - C. 64.

2. Комлаикий В. И. Пчеловодство : [учеб. пособие для студ. биол. спец.] / В. И. Комлацкий, Г. Я. Кошевой, С. В. Логинов. - Краснодар : Кубанский гос. аграр. ун-т. Кафедра частной зоотехнии и свиноводства, 2000. $-84 \mathrm{c.}$

3. Мирось В. В., Бабрика І. Г. Бджільництво : навч. посібник / В. В. Мирось, І. Г. Бабрика. - Х. : Харківський нац. аграр. ун-т. ім. В. В. Докучаєва, 2007. - $278 \mathrm{c}$.

4. Боднарчук Л. I. Племінна робота у бджіль- розплоду збільшується на $17,8 \%$, а кількість вихованого за цей період розплоду - на 9,8 \%, кількість корму на одну вуличку бджіл і сила сімей на початку зими зменшується на 4,7 \% і 16,4\%. Отже, отриманий результат вказує на негативний вплив підгодівлі бджолиних сімей цукровим сиропом під час їх підготовки до зимівлі в період з 1 до 15 вересня.

Висновок. У лісостеповій зоні Лівобережжя України під час підготовки бджолиних сімей до зимівлі $з$ третьої декади липня відбувається поступове зменшення вирощування розплоду незалежно від наявності продуктивного медозбору.

$\mathrm{У}$ разі поповнення запасів корму на зимовий період шляхом згодовування цукрового сиропу період від початку зменшення до припинення виховання розплоду збільшується на $17,8 \%$, а кількість вихованого розплоду за цей період - на $9,8 \%$, кількість корму на одну вуличку бджіл і сила сімей на початку зими зменшується відповідно на 4,7 \% і 16,4 \%.

ництві 3 основами біометрії / Л.І.Боднарчук, I. Г. Багрій, С. І. Бугера. - К. : Інститут бджільництва ім. П. І. Прокоповича УААН, 1996. - С. 34.

5. Поліщук В. П. Бджільництво / В. П. Поліщук. - Львів : Ред. журналу «Український пасічник», 2001. - 296 с.

6. Кононенко В. К. Практикум з основ наукових досліджень у тваринництві / В.К. Кононенко, І. І. Ібатуллін, В. С. Патров. - К., 2000. $96 \mathrm{c}$.

7. Смирнов В. Энциклопедия пчеловода / В. Смирнов. - М. : РИПОЛ КЛАССИК, 2003. $384 \mathrm{c}$. 